\title{
Ontogenesis of insulin processing in fetal rat hepatocytes
}

\author{
M. R. Benedict and R. A. Richman \\ Department of Pediatrics, SUNY Health Science Center at Syracuse, Syracuse, New York, USA
}

\begin{abstract}
Summary. We studied insulin processing and hepatic glycogenesis in cultured hepatocytes isolated from rat fetuses of 17,19 , and 21 days of gestation. Steady-state insulin binding increased by $250 \%$ between days 17 and 19 , from $145 \pm 8$ to $361 \pm 52 \mathrm{fmol} / \mathrm{mg}$ protein, and by an additional $40 \%$ $\left(405 \pm 69 \mathrm{fmol} / \mathrm{mg}\right.$ protein) by 21 days of gestation. At $37^{\circ} \mathrm{C}$, ${ }^{125} \mathrm{I}$-insulin was rapidly $\left(\mathrm{t}_{1 / 2}<5 \mathrm{~min}\right)$ internalized by hepatocytes at all three ages, reaching maximal levels $(63-76 \%$ of the total cell-associated radioactivity) by $15 \mathrm{~min}$. ${ }^{125}$ I-labelled degradation products appeared rapidly $\left(\mathbf{t}_{1 / 2}<15 \mathrm{~min}\right)$ within the cells. Yet, the majority (68-77\%) of the intracellular radioactivity consisted of intact ${ }^{125}$-insulin, even after $4 \mathrm{~h}$ at $37^{\circ} \mathrm{C}$. Hepatocytes pre-loaded with ${ }^{125} \mathrm{I}$-insulin and then acidstripped of surface-bound radioactivity, rapidly released both intact ${ }^{125}$ I-insulin (retroendocytosis) and its radiolabelled degradation products. While intact insulin was initially released more rapidly $\left(\mathrm{t}_{12}<6 \mathrm{~min}\right)$, and reached a pla-
\end{abstract}

teau after $15-30 \mathrm{~min}$, the degradation products continued to accumulate in the medium for at least $4 \mathrm{~h}$. Methylamine inhibited intracellular ${ }^{125} \mathrm{I}$-insulin degradation at all three gestational ages and also blocked insulin-stimulated glycogenesis in 19- and 21-day hepatocytes, without altering basal glycogen synthesis. Insulin-stimulated glycogenesis was not induced in 17-day fetal rat hepatocytes in control or methylamine-treated cultures. We conclude that both degradative and retroendocytotic pathways for processing insulin are present in fetal rat hepatocytes by 17 days of gestation. Further, insulin-receptor processing was functionally related to the glycogenic action of insulin in responsive 19- and 21-day fetal rat hepatocytes

Key words: Insulin, fetal rat hepatocytes, glycogen, endocytosis, degradation, retroendocytosis.
Numerous clinical and experimental observations suggest that insulin plays a major role in regulating fetal growth and metabolism during late gestation [1-3]. While the growth-promoting actions of insulin may be mediated through indirect mechanisms, such as interaction with insulin-like growth factor-I (IGF-I) receptors [3-5], its effects on hepatic glycogenesis late in gestation appear to involve classic insulin receptor-mediated pathways. Insulin binding to 18-day fetal rat hepatocytes in culture preceded insulin-stimulated glycogenesis and insulin degradation [6-8]; both events were inhibited by agents which interfere with insulin-receptor processing. While Sodoyez et al. [9] reported that the processing of insulin by intact fetal rat livers in vivo increased between 17 and 21 days of gestation, little information is available regarding the cellular events involved in insulin processing by the fetal liver. These events have been extensively studied in adult target tissues $[10,11]$. Hormone binding to cell surface receptors is followed by receptor-mediated endocytosis of insulinreceptor complexes with the subsequent dissociation of these complexes within pre-lysosomal acidic endosomal compartments. In adipocytes [12] and hepatocytes [13] isolated from adult rats, the intracellular insulin is processed via two distinct pathways. One culminates in insulin catabolism and the release of degradation products, while the second pathway results in the release of intact hormone; the majority of internalized receptors appear to be recycled back to the cell surface [14]. Very little is known about the maturation of these degradative and retroendocytotic pathways during fetal development or their relationship to the biological actions of insulin.

We have used cultured hepatocytes isolated from rat fetuses of 17,19 , and 21 days of gestation to directly examine the metabolic processing of insulin. With this culture system, we explored the possibility that fetal hepatocytes, like their adult counterparts, release intact insulin through a retroendocytotic pathway. To evaluate the physiological significance of these events during fetal development, we compared various aspects of insulin processing and insulin-stimulated glycogenesis, in the 
presence and absence of methylamine, an inhibitor of endosomal processing of insulin-receptor complexes.

\section{Materials and methods}

\section{Animals}

Timed-pregnant Sprague-Dawley rats were purchased from Taconic Laboratories (Germantown, NY, USA). After the mothers were killed by $\mathrm{CO}_{2}$ asphyxiation, in accordance with National Institutes of Health guidelines for the humane treatment of laboratory animals, we delivered the fetuses by Caesarean section between the 17th and 21 st day of gestation, as indicated. The fetuses were immediately decapitated and their livers were rapidly removed.

\section{Materials}

Tissue culture media and reagents were purchased from Grand Island Biological Co. (Grand Island, NY, USA) and tissue culture dishes from Falcon Plastics (Los Angeles, Calif., USA). Insulin-free, RIA grade borine serum albumin (BSA), bovine insulin, dexamethasone, methylamine, and type IV collagenase were obtained from Sigma Chemical Co. (St. Louis, Mo., USA). Anthrone reagent and diaminobenzoic acid were purchased from Aldrich Chemical Co. Inc. (Milwaukee, Wis., USA). Iodobead radioiodination reagent was supplied by Pierce Chemical Co. (Rockford, Ill., USA). Na ${ }^{125} \mathrm{I}$, D-U- ${ }^{14} \mathrm{C}$-glucose, and ACS scintillation cocktail were purchased from Amersham Corp. (Arlington Heights, Ill., USA). Rat tail collagen was prepared by extraction of rat tail tendons in $0.1 \%$ acetic acid for $72 \mathrm{~h}$ at $4^{\circ} \mathrm{C}$. After centrifugation $\left(12,000 \times g, 4^{\circ} \mathrm{C}, 2 \mathrm{~h}\right)$ to remove insoluble material, the supernatant fraction was lyophilized. Prior to use, collagen was rehydrated in sterile distilled water and adjusted to $\mathrm{pH} 3.5 \mathrm{using} 1 \mathrm{~mol} / \mathrm{l}$ acetic acid. This material $(0.08 \mathrm{ml}$ of a $2 \mathrm{mg} / \mathrm{ml}$ stock solution) was permitted to gel on the surface of the tissue culture dishes in an ammonium hydroxide vapour bath for $1 \mathrm{~h}$ $\left(160 \mu \mathrm{g}\right.$ collagen $/ 8.8 \mathrm{~cm}^{2}$ well $)$, and washed with $1 \mathrm{ml}$ of sterile water before plating the hepatocytes.

\section{Iodination of insulin}

Insulin was iodinated to a specific activity of $20-30 \mu \mathrm{Ci} / \mu \mathrm{g}$, using the iodobead reagent and separated from unreacted ${ }^{125}$ I by chromatography on Sephadex G-25 as previously described [15].

\section{Preparation of fetal rat hepatocytes}

Fetal rat hepatocytes were isolated by a modification of our previously described collagenase dissociation method [15]. The digestion buffer was changed to Hanks' balanced salt solution with $10 \mathrm{mmol} / \mathrm{HEPES}, 4.0 \mathrm{mmol} / \mathrm{l}$ calcium chloride, and $0.7 \% \mathrm{BSA}$; the collagenase concentration was $300 \mathrm{U} / \mathrm{ml}$. Tissue culture dishes $\left(8.8 \mathrm{~cm}^{2}\right.$ wells) were coated with rat tail collagen $(160 \mu \mathrm{g} / \mathrm{well})$. Hepatocytes were plated at a density of $0.7-1.0 \times 10^{6}$ cells/well, in $3.5 \mathrm{ml}$ of M-199, containing $10 \%$ fetal bovine serum and dexamethasone $\left(1 \times 10^{-7} \mathrm{~mol} / \mathrm{l}\right)$. Dexamethasone was included during the first $4 \mathrm{~h}$ to enhance plating efficiency. The ammonium chloride rinse we previously used for lysing erythrocytes, was omitted, as these latter cells were demonstrated not to adhere to the collagen-coated dishes. After $4 \mathrm{~h}$, the medium was changed to one containing $10 \%$ fetal bovine serum, but not dexamethasone. After $18 \mathrm{~h}$, the cells were rinsed three times with serum-free M-199 and incubated for another $2 \mathrm{~h}$ in the absence of serum prior to initiation of the experimental protocol (zero time). Thus, all cultures were exposed to serum only during the initial $22 \mathrm{~h}$ after plating. At zero time, the cell densities averaged $0.56 \pm 0.24 \times 10^{6}$ cells/well and were not affected by the donor age
Incubation in serum-free medium for up to $72 \mathrm{~h}$ resulted in only a small $(<15 \%)$ further loss of cells.

\section{Insulin binding}

Hepatocytes were incubated at temperatures of $4^{\circ}$ and $37^{\circ} \mathrm{C}$ with $1 \mathrm{ml}$ of binding buffer (M-199 with Hanks' salts, $1 \%$ BSA, pH 7.8) for at least $30 \mathrm{~min}$ prior to addition of ${ }^{125} \mathrm{I}$-insulin $(0.5 \mathrm{nmol} / \mathrm{l})$; parallel cultures received ${ }^{125} \mathrm{I}$-insulin plus unlabelled insulin $(1 \mu \mathrm{mol} / \mathrm{l})$ for determination of non-specific binding. ${ }^{125}$ I-Insulin binding to collagen-coated wells without cells present was less than $6 \%$ of the total binding to collagen-coated wells containing hepatocytes, and was not reduced by co-incubation with $1 \mu \mathrm{mol} / 1$ unlabelled insulin. Therefore, specific binding [total cpm (absence of unlabelled insulin) - non-specific cpm (presence of $1 \mu \mathrm{mol} / \mathrm{l}$ unlabelled insulin)] was corrected for the total non-specific binding for the collagen substrate and the cell monolayer. The labelled and unlabelled insulin were equilibrated for $30 \mathrm{~min}$ at the appropriate temperature before addition. At the indicated times, the medium was decanted and the cells were rinsed four times with ice-cold phosphate buffered saline (PBS). The dishes were air-dried and the hepatocytes then solubilized overnight in $1 \mathrm{ml}$ of $0.5 \mathrm{~mol} / 1 \mathrm{NaOH}$. The radioactivity in an aliquot $(0.5 \mathrm{ml})$ of the solubilized cells was determined. Total cellular protein content was measured in another aliquot $(0.04 \mathrm{ml})$ by the method of Lowry et al. [16].

\section{Insulin processing}

We assessed several aspects of insulin processing: ${ }^{125} \mathrm{I}$-insulin internalization, intracellular degradation, and reappearance in the medium. The location of cell-associated ${ }^{125}$ I-insulin was determined by a modification of the method of Haigler et al. [17]. Following incubation with ${ }^{125} \mathrm{I}$-insulin (parallel cultures received $1 \mu \mathrm{mol} / \mathrm{l}$ unlabelled insulin for estimation of non-specific association) for various times at $4^{\circ}$ and $37^{\circ} \mathrm{C}$, the hepatocytes were rinsed with ice-cold $\mathrm{M}$ 199 containing $1 \%$ BSA and placed on ice. Surface-bound ${ }^{125} \mathrm{I}$-insulin was removed by treating the cultures for $6 \mathrm{~min}$ with $1 \mathrm{ml}$ of ice-cold $0.2 \mathrm{~mol} / \mathrm{l}$ acetic acid containing $0.5 \mathrm{~mol} / \mathrm{I} \mathrm{NaCl}(\mathrm{pH} 2.5)$. In preliminary experiments, this procedure removed more than $95 \%$ of the total cell-associated radioactivity (presumed to be present only on the cell surface) when hepatocytes had been pre-incubated with ${ }^{125} \mathrm{I}$-insulin for $30 \mathrm{~min}$ at $4{ }^{\circ} \mathrm{C}$, a temperature at which internalization of hormone does not occur. The intracellular radioactivity remaining after acetic acid stripping was then extracted in $1 \mathrm{ml}$ of $1 \mathrm{~mol} / \mathrm{l}$ acetic acid, containing $4 \mathrm{~mol} / \mathrm{l}$ urea and $0.1 \%$ Triton X-100 [18] for subsequent determination of intracellular insulin degradation.

${ }^{125}$ I-Insulin degradation was estimated by measuring the radioactivity soluble in ice-cold trichloroacetic acid (TCA). Extracts $(0.5 \mathrm{ml})$ of cell-associated radioactivity were diluted with $0.5 \mathrm{ml}$ of PBS containing $1 \%$ BSA and incubated with $1 \mathrm{ml}$ of ice-cold $20 \%$ TCA for $10 \mathrm{~min}$ at $0^{\circ} \mathrm{C}$. Precipitable material (intact hormone) was separated from soluble radioactivity (degradation products) by centrifugation $\left(1200 \times g\right.$ at $4^{\circ} \mathrm{C}$ for $\left.15 \mathrm{~min}\right)$. To confirm these estimates of ${ }^{125}$ I-insulin degradation, some extracts were also analysed by size exclusion HPLC using a Protein-Pak 125 column (Waters Assoc.; Milford, Mass., USA).

To examine the kinetics of intact and degraded ${ }^{125} \mathrm{I}$-insulin release, hepatocytes were pre-incubated with ${ }^{125} \mathrm{I}$-insulin at $37^{\circ} \mathrm{C}$; parallel cultures also received $1 \mu \mathrm{mol} / \mathrm{l}$ of unlabelled insulin for estimation of non-specific release. After $30 \mathrm{~min}$ (the time when maximum specific intracellular concentrations of insulin were attained), the labelling medium was removed, the hepatocytes were rinsed with icecold M-199 containing 1\% BSA, and placed on ice. Surface-bound ${ }^{125} \mathrm{I}$-insulin was then removed by the acid-saline dissociation method as outlined above. The cultures were rinsed again with warm medium and incubated for an additional $4 \mathrm{~h}$ at $37^{\circ} \mathrm{C}$. At various times the medium was collected and assayed for insulin degradation by the TCA precipitation method; the data were corrected for non-spe- 

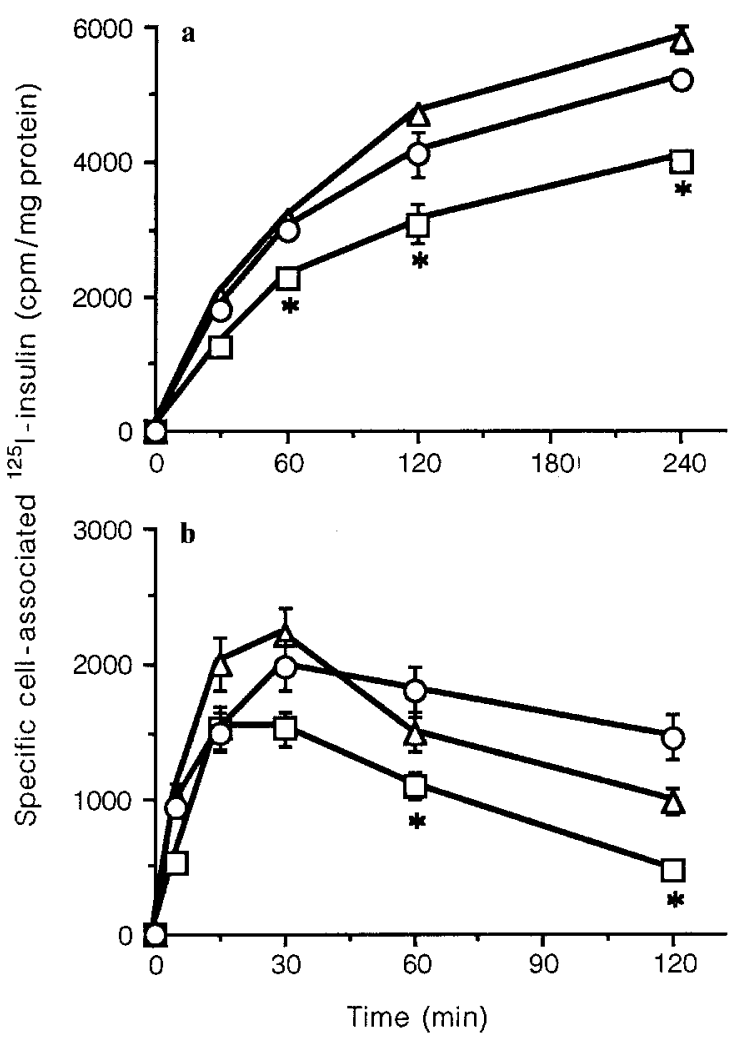

Fig. 1a,b. Effect of temperature on the time course of insulin binding. Cultured hepatocytes from 17- $(\square), 19-(\triangle)$, and 21- (O) dayold fetal rats were incubated at $4^{\circ} \mathrm{C}$ (a) and $37^{\circ} \mathrm{C}$ (b) with ${ }^{125} \mathrm{I}$-insulin $\left(0.5 \mathrm{nmol} / 1 ; 1 \times 10^{5} \mathrm{cpm}\right)$ in the presence (non-specific binding) and absence (total binding) of unlabelled insulin $(1 \mu \mathrm{mol} / 1)$ in M-199 with Hanks' salts, containing 1\% BSA. At the indicated times, the labelling medium was decanted and the cells were rapidly rinsed four times with ice-cold PBS. The cell monolayers were then solubilized overnight in $1 \mathrm{ml}$ of $0.5 \mathrm{~mol} / 1 \mathrm{NaOH}$ per well and the protein content and radioactivity determined. The data are expressed as specific cellassociated cpm per mg protein; means \pm SEM of three experiments are shown. ${ }^{*} p<0.01$ for differences between 17 - and 21 -day cultures at the indicated times

cific release of ${ }^{125}$ I-labelled material, which averaged $12.6 \pm 3.4 \%$ (mean \pm SEM) of the total radioactivity released into the medium.

\section{Glycogen determinations}

Fetal hepatocyte cultures were incubated in the presence of dexamethasone for $48 \mathrm{~h}$ and were then washed three times with warm M199 containing $0.25 \%$ BSA. This exposure to dexamethasone was included as it had previously been shown to be required for ensuring a glycogenic response to insulin in cultured fetal rat hepatocytes $[6,7]$. After an additional 4-h incubation with D-U- ${ }^{14} \mathrm{C}$-glucose $(1.0 \mu \mathrm{Ci} /$ well) in $\mathrm{M}-199$ containing $0.25 \% \mathrm{BSA}$ and the indicated concentrations of insulin, total cellular glycogen and ${ }^{14} \mathrm{C}$-glucose incorporation into glycogen were determined by a modification of the ethanol-SO $\mathrm{SO}_{4}$ precipitation method of Van Handel [19]. Briefly, hepatocytes were disrupted by freeze-thawing in $0.5 \mathrm{ml}$ of $0.03 \mathrm{~mol} / 1 \mathrm{HCl}$, scraped from the surface of the culture plates using a rubber policeman, and transferred to polypropylene conical centrifuge tubes; the plates were rinsed with an additional $0.1 \mathrm{ml} 0.03 \mathrm{~mol} / \mathrm{h} \mathrm{HCl}$. Glycogen standards were prepared in $0.6 \mathrm{ml}$ of $0.03 \mathrm{~mol} / \mathrm{H} \mathrm{HCl}$ for subsequent quantitation of total cellular glycogen levels by the Anthrone reaction [19]. Saturated $\mathrm{Na}_{2} \mathrm{SO}_{4}(0.05 \mathrm{ml})$ was added to both the cell lysates and glycogen standards, followed by the addition of $1.3 \mathrm{ml}$ of $95 \%$ ethanol. The glycogen which precipitated was isolated by centrifugation at $1800 \times \mathrm{g}$ for $10 \mathrm{~min}$. The supernatant fraction was removed by aspiration and the pellet was washed with $1.0 \mathrm{ml}$ of $95 \%$ ethanol. After a second centrifugation, the supernatant fraction was discarded and the pellet was dissolved in $0.6 \mathrm{ml}$ of concentrated formic acid. An aliquot $(0.3 \mathrm{ml})$ was diluted in $\mathrm{H}_{2} \mathrm{O}$ and ACS scintillation cocktail and counted in a Beckman LS 3300 liquid scintillation counter to measure the amount of $\mathrm{D}-\mathrm{U}-{ }^{14} \mathrm{C}$-glucose incorporation into glycogen. To the remainder, $3.0 \mathrm{ml}$ of $0.2 \%$ Anthrone reagent in $70 \%$ sulphuric acid was added. The tubes were heated for 20 min at $90^{\circ} \mathrm{C}$, rapidly cooled in cold water, and thoroughly mixed; absorbance was measured at $620 \mathrm{~nm}$ to determine the total amount of glycogen present.

\section{Statistical analysis}

All experiments were performed using triplicate cultures for each condition (i.e. three cultures for total binding and three cultures for non-specific binding). Three such experiments were often performed; some figures (as indicated in the legends), however, depicted data from only one experiment. In all cases, the results were expressed as the mean \pm SEM. Statistical analysis using a two-tailed Student's $t$-test (StatView; Brainpower, Inc., Calabasas, Calif., USA) was performed on a Macintosh SE microcomputer (Apple Computer, Inc., Cupertino, Calif., USA).

\section{Results \\ Developmental changes in insulin binding}

The effect of temperature on developmental changes in the time course of insulin binding to cultured fetal rat hepatocytes is shown in Figure 1 . At $37^{\circ} \mathrm{C}$, the levels of cellassociated radioactivity resulting from ${ }^{125} \mathrm{I}$-insulin uptake by hepatocytes isolated from 17-, 19-, and 21-day rat fetuses were initially similar, increasing rapidly to a maximum by $30 \mathrm{~min}$. Continued incubation resulted in a rapid loss of cell-associated radioactivity, particularly at 17 days of gestation, probably reflecting processing and release of the labelled hormone. In cultures from 17-day fetuses, the percentage of radioactivity associated with the hepatocytes after $2 \mathrm{~h}$ had declined to only about $25 \%$ of that present at $30 \mathrm{~min}$. This loss occurred more slowly in cultures prepared from fetal rats later in gestation; by 21 days, almost $75 \%$ of the peak radioactivity was still cell-associated after $2 \mathrm{~h}$. In contrast, at $4{ }^{\circ} \mathrm{C},{ }^{125} \mathrm{I}$-insulin binding occurred more slowly, but increased steadily with time. For all three gestational ages studied, it approached a plateau by $4 \mathrm{~h}$, which was at least twice the maximal levels of binding observed at $37^{\circ} \mathrm{C}$.

Developmental differences in maximal specific ${ }^{125}$ I-insulin binding were small at low concentrations $(0.5-$ $3 \mathrm{nmol} / \mathrm{l}$ ) of the hormone; binding to 17 -day fetal hepatocytes was only $25-30 \%$ less than that occurring in cultures from 19- or 21-day fetuses (Fig. 2). In contrast, at saturating levels of insulin, large developmental differences in insulin binding capacity became apparent. At insulin concentrations greater than $30 \mathrm{nmol} / \mathrm{l}$, there was a dramatic increase $(250 \%)$ in the levels of cell-associated ${ }^{125}$ I-insulin late in gestation (19-21 days) which was not observed at 17 days of gestation. Under steady-state conditions $\left(4^{\circ} \mathrm{C}\right.$ for $24 \mathrm{~h}$ ), the levels of maximum cell-associated insulin increased from $145 \pm 8 \mathrm{fmol} / \mathrm{mg}$ protein in 17-day cells to $361 \pm 52$ and $405 \pm 69 \mathrm{fmol} / \mathrm{mg}$ protein in hepatocytes iso- 


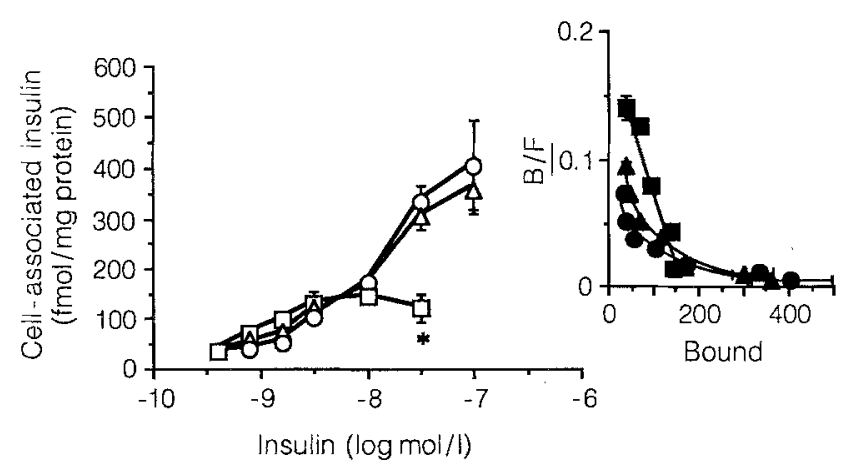

Fig. 2. Changes in the maximal insulin binding capacity with gestational age. Hepatocytes from 17- $(\square), 19-(\triangle)$, and 21- (O) dayfetal rats were incubated at $4^{\circ} \mathrm{C}$ for $24 \mathrm{~h}$ (steady-state binding) with ${ }^{125}$ I-insulin $(0.5 \mathrm{nmol} / \mathrm{l})$ in the presence of increasing concentrations of unlabelled insulin. ${ }^{125}$ I-Insulin binding was measured at each hormone concentration and corrected for non-specific binding (residual binding in presence of $1 \mu \mathrm{mol} / 1$ unlabelled insulin); the resulting displacement curves were used to calculate the total amount of hormone specifically associated with the cells. The data are expressed as fmol cell-associated insulin per mg protein; each point represents the mean \pm SEM for three experiments. * $p<0.01$ for the difference between 17- and 21-day cultures at the indicated concentration of insulin. Scatchard plots of the data are shown in the inset (solid symbols)

lated from 19- and 21-day fetal rats, respectively. Scatchard plots (Fig.2, inset) of these competitive binding data shifted from linear to curvilinear between days 17 and 19 of gestation, suggesting that a second class of binding sites with lower affinity for insulin appeared during this period of gestation.

\section{Internalization and degradation of insulin}

We next carried out a series of experiments designed to investigate the fate of insulin when bound to fetal hepatocytes. The cellular distribution (surface vs intracellular) of insulin was determined following incubation of ${ }^{125} \mathrm{I}$-insulin $(0.5 \mathrm{nmol} / \mathrm{l})$ with fetal hepatocytes at different temperatures (Fig. $3 \mathrm{a}$ ). We used a low concentration $(0.5 \mathrm{nmol} / \mathrm{l})$ of insulin for these experiments in order to minimize the effects of the large developmental differences in binding capacity seen at higher concentrations of insulin (Fig.2). At $4^{\circ} \mathrm{C}$, most $(>80 \%)$ of labelled insulin which was bound to the hepatocytes (regardless of the gestational age of the donors) remained on the cell surface (i.e. susceptible to acid dissociation) throughout the incubation period $(2 \mathrm{~h})$. However, at $37^{\circ} \mathrm{C},{ }^{125} \mathrm{I}$-insulin rapidly $\left(\mathrm{t}_{1 / 2}<5 \mathrm{~min}\right)$ entered an acid-resistant, intracellular compartment at all three gestational ages studied. By $30 \mathrm{~min}$, the majority of cell-associated ${ }^{125} \mathrm{I}$-insulin was present within an intracellular compartment. The percentage of ${ }^{125}$ I-insulin located within the cells tended to be higher in hepatocytes derived from 17 -day fetuses $(76 \%)$, and decreased with gestational age ( $63 \%$ by 21 days of gestation); however, these differences were not statistically significant.

The effect of temperature and gestational age on the nature (intact vs degraded) of the internalized ${ }^{125} \mathrm{I}$-insulin was also determined (Fig. 3 b). Intracellular degradation of ${ }^{125} \mathrm{I}$-insulin, like insulin internalization, was temperature dependent. At $37^{\circ} \mathrm{C}$, the percentage of degradation products within the hepatocytes reached equilibrium by 60 min at all three ages. The proportion of degradation products relative to the total intracellular radioactivity also tended to be higher in 17-day hepatocytes (32\%), and decreased with gestational age $(23 \%$ by 21 days). The other $68-77 \%$ of the ${ }^{125}$ I-labelled material within the cells at $60 \mathrm{~min}$ remained precipitable by TCA and was indistinguishable from intact insulin by size exclusion HPLC. The apparent steady-state probably reflects an equilibrium between the rates of insulin internalization and expulsion
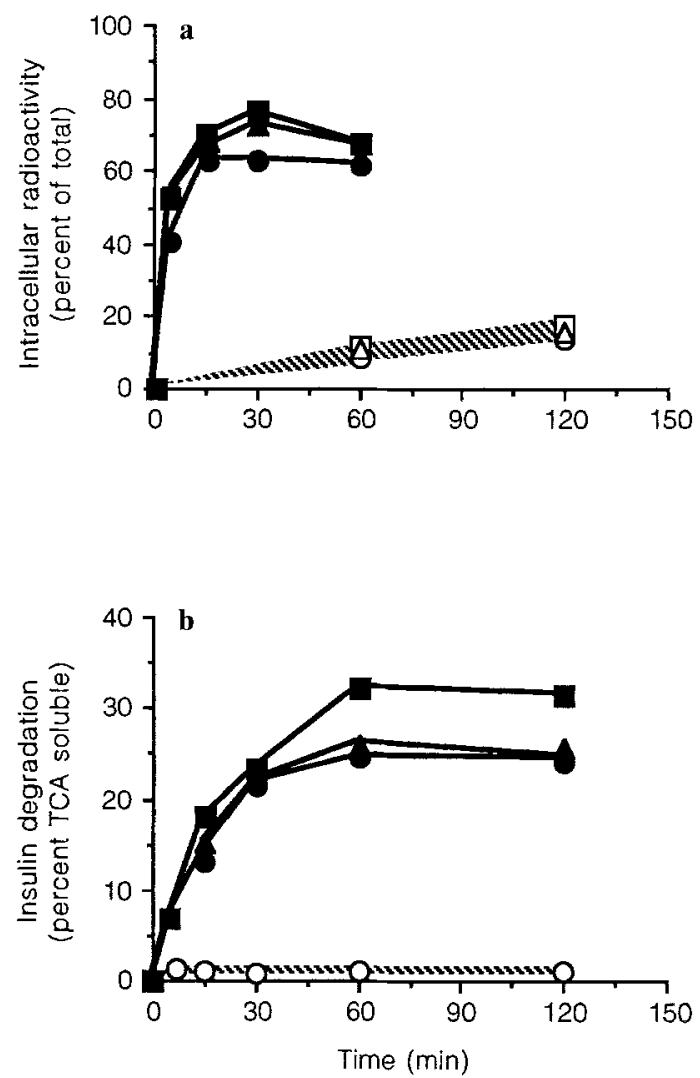

Fig.3a,b. Temperature-dependent insulin internalization and degradation. Fetal rathepatocytes $(17(\square), 19(\Delta)$, and $21(0)$ days of gestation) were incubated with ${ }^{125}$ I-insulin $(0.5 \mathrm{nmol} / \mathrm{l})$ in the presence and absence of unlabelled insulin $(1 \mu \mathrm{mol} / \mathrm{l})$ at $37^{\circ}$ (solid symbols) and $4^{\circ} \mathrm{C}$ (open symbols). At the indicated times, the cells were rapidly washed with ice-cold PBS and placed on ice. Surfacebound ${ }^{125} \mathrm{I}$-insulin was removed by treatment with $0.2 \mathrm{~mol} / \mathrm{l}$ acetic acid containing $0.5 \mathrm{~mol} / \mathrm{l} \mathrm{NaCl}$ for $6 \mathrm{~min}$. The radioactivity remaining associated with the cells (intraceliular) was solubilized in $1 \mathrm{ml}$ of $1 \mathrm{~mol} / \mathrm{l}$ acetic acid containing $4 \mathrm{~mol} / 1$ urea and $0.1 \%$ Triton $X-100$. a The percentage of the total cell-associated radioactivity (surface + intracellular) which is intraceliular at various times is shown for all three fetal ages; the data have been corrected for differences in protein content as well as non-specific uptake of ${ }^{125} \mathrm{I}$-insulin. b The radioactivity soluble in $10 \%$ ice-cold TCA (degraded insulin) was determined after dilution of $0.5 \mathrm{ml}$ of the intracellular extract with $0.5 \mathrm{ml}$ of PBS with $2 \% \mathrm{BSA}$. The data are expressed as a percentage of the total intracellular radioactivity which is soluble in TCA. At $4^{\circ} \mathrm{C}$, no degradation products were detected (only the data for the 21-day hepatocytes are shown). Means of triplicate cultures are shown; SEM's averaged less than $8 \%$ of the means and are not shown 


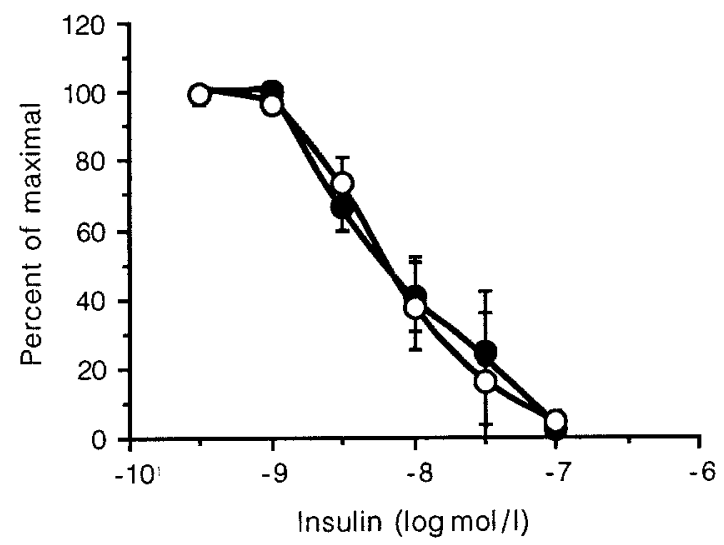

Fig. 4. Correlation between insulin binding and degradation. Hepatocytes from 21 -day fetal rats were incubated at $37^{\circ} \mathrm{C}$ with ${ }^{125} \mathrm{I}$-insulin $(0.5 \mathrm{nmol} / \mathrm{l})$ in the presence of increasing concentrations of unlabelled insulin. After $30 \mathrm{~min}$, the cells were rinsed four times with ice-cold PBS and extracted in $1 \mathrm{~mol} / \mathrm{l}$ acetic acid, $4 \mathrm{~mol} / \mathrm{l}$ urea, and $0.1 \%$ TCA. Both total cell-associated radioactivity (binding, $O$ ) and that soluble in $10 \%$ TCA (degraded insulin, - ) were determined. The data have been normalized for differences in protein content and corrected for non-specific binding and degradation (in the presence of $1 \mu \mathrm{mol} / 1$ unlabelled insulin); means \pm SEM for triplicate cultures are shown

from the cells of ${ }^{125}$ I-labelled insulin and its degradation products. At $4{ }^{\circ} \mathrm{C}$, no degradation products were detectable at any gestational age; data shown only for 21-day fetal hepatocytes.

To confirm that the internalization and degradation of insulin occurred through a receptor-mediated pathway, we compared the inhibition of insulin binding and insulin degradation by increasing concentrations of unlabelled insulin (Fig. 4). The curves generated could be superimposed upon each other (correlation coefficients $>0.99$ ) at all three gestational ages; however, the results are shown only for the 21-day fetal hepatocytes as no developmental differences were observed. Half-maximal inhibition of both binding and degradation occurred at approximately $5 \mathrm{nmol} / \mathrm{l}$ unlabelled insulin. Based on these findings, it appeared that insulin degradation in fetal rat hepatocytes, as previously suggested [7], was predominantly a receptormediated process.

We next assessed the kinetics of insulin release from hepatocytes prepared from fetuses of 17 and 21 days of gestation. The cells were pre-incubated with ${ }^{125} \mathrm{I}$-insulin at $37^{\circ} \mathrm{C}$ for $30 \mathrm{~min}$, rinsed thoroughly with ice-cold M-199 and treated with acetic acid-saline (see Materials and methods) to remove extracellular and surface-bound ${ }^{125} \mathrm{I}$ insulin, and then warmed to $37^{\circ} \mathrm{C}$. The nature of the radioactivity subsequently released into fresh culture medium was determined by the TCA precipitation method at the indicated times (Fig. 5 a, b). The release of intact ${ }^{125} \mathrm{I}-$ insulin $\left(\mathrm{t}_{1 / 2}<6 \mathrm{~min}\right)$ during the first 15-20 min of incubation was slightly more rapid than the release of ${ }^{125} \mathrm{I}$ labelled degradation products at 17 and 21 days of gestation. Whereas the levels of intact insulin in the medium reached a plateau after 15-30 min, degradation products continued to accumulate in the medium for at least $4 \mathrm{~h}$. Hepatocytes from 17-day-old donors released about
M. R. Benedict and R. A. Richman: Insulin processing by fetal hepatocytes

$67 \%$ more degraded insulin than those from 21-day-old rats. We did not detect any insulin degrading activity in the medium conditioned by cultured hepatocytes during $48 \mathrm{~h}$ of incubation.

\section{Relationship between insulin processing and insulin-stimulated glycogenesis}

To assess the possible relationship between insulin processing and the metabolic actions of insulin during late gestation, we compared the effects of the acidotropic agent, methylamine, on insulin binding, internalization, and degradation, to its effects on insulin-stimulated glycogen synthesis. We elected to use methylamine at a concentration of $10 \mathrm{mmol} / \mathrm{l}$ for these studies, even though more complete inhibition of hormone degradation was

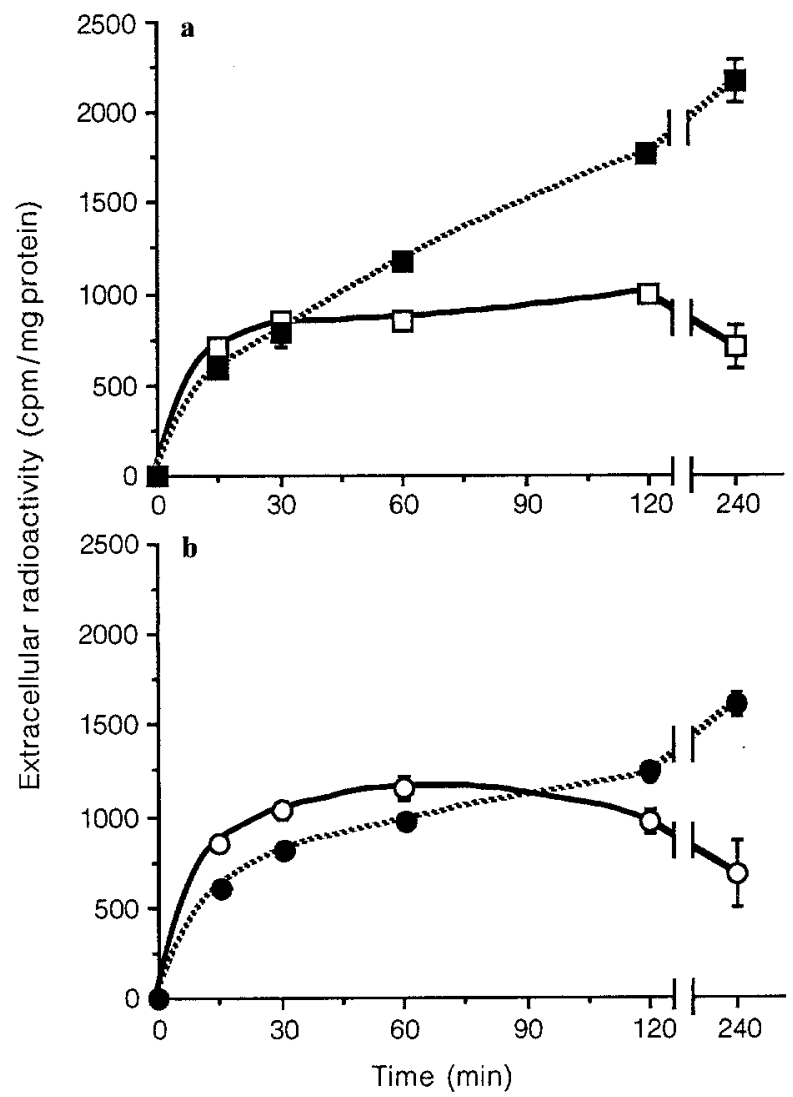

Fig.5a,b. Release of intact ${ }^{125} \mathrm{I}$-insulin and its degradation products. Fetal hepatocytes from $17(\square ; \mathbf{a})$ and $21(\mathrm{O} ; \mathbf{b})$ days of gestation were incubated with ${ }^{125} \mathrm{I}$-insulin $(0.5 \mathrm{nmol} / \mathrm{l})$ at $37^{\circ} \mathrm{C}$ in the presence and absence of unlabelled insulin $(1 \mu \mathrm{mol} / 1)$. After $30 \mathrm{~min}$, the medium containing unbound ${ }^{225} I$-insulin was removed, the cultures were rinsed with ice-cold PBS, and the surface-bound ${ }^{125} \mathrm{I}$-labelled material was removed by incubation with acetic acid-saline on ice. The cells were rinsed again with cold PBS, followed by the addition of fresh warm $\left(37^{\circ} \mathrm{C}\right) \mathrm{M}-199$. At the indicated times, the medium was removed from six wells (three each for assessment of total and non-specific interactions), diluted 1:1 with PBS containing 2\% BSA, and precipitated with ice-cold $10 \%$ (final concentration) TCA. The data are expressed as specific cpm for intact (TCA-precipitable; open symbols, solid line) and degraded (TCA-soluble; closed symbols, dotted line) insulin released into the medium and have been normalized for differences in the protein content of the cells; nonspecific release has been subtracted. Means \pm SEM for three experiments are shown 

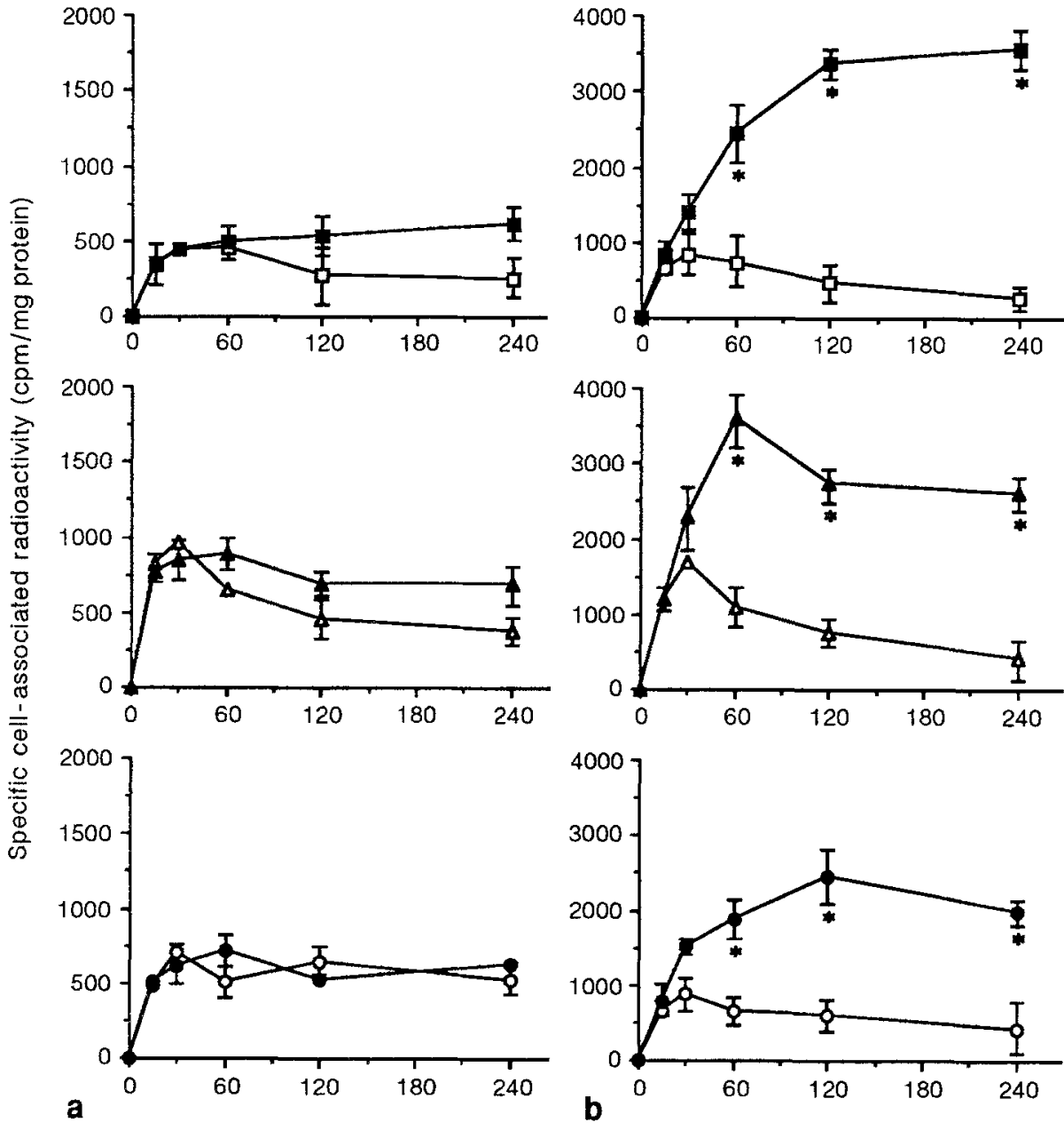

Fig. 6a,b. Effect of methylamine on the localization of cell-associated ${ }^{125}$ I-insulin. Fetal rat hepatocytes $(17(\square), 19(\triangle)$, and $21(O)$ days of gestation) were incubated at $37^{\circ} \mathrm{C}$ with ${ }^{125}$ I-insulin $(0.5 \mathrm{nmol} / 1)$, with (non-specific) and without unlabelled insulin $(1 \mu \mathrm{mol} / 1)$ and methylamine $(10 \mathrm{mmol} / \mathrm{l}$; closed sym-

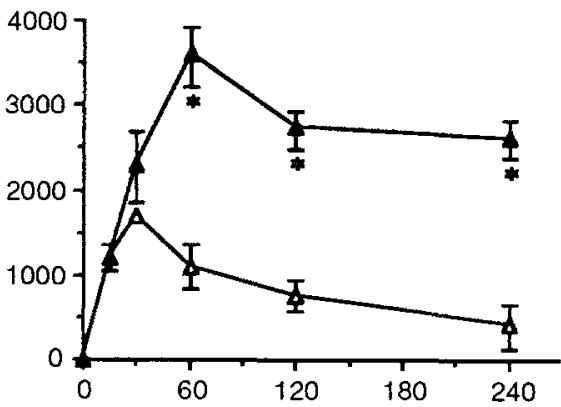
bols) for the indicated times. After rinsing four times with ice-cold PBS, surfacebound radioactivity was removed with acid-saline and the remaining ${ }^{125} \mathrm{I}$-labelled material associated with the cells (intracellular) was solubilized in $0.5 \mathrm{~mol} / 1 \mathrm{NaOH}$. The amount of radioactivity was determined in an aliquot of each fraction. a Represents surface-associated radioactivity and $\mathbf{b}$ represents intracellular radioactivity. The data from control cultures are depicted in open symbols and the methylamine-treated cultures in closed symbols. The results are expressed as specific cell-associated radioactivity (surface or internal) per $\mathrm{mg}$ protein; means \pm SEM for triplicate cultures (three determinations per culture) are shown. * $p<0.01$ for the differences between control and methylaminetreated cultures of the same age at the indicated times

Time (min)

obtained at higher concentrations (data not shown). In the presence of $30 \mathrm{mmol} / \mathrm{l}$ methylamine, numerous large vesicular structures appeared in the cytoplasm. Most likely, the high levels of amine within the endosomal system caused the vesicles to become hyperosmotic, resulting in diffusion of water from the cytoplasm into the vesicles to restore osmotic equilibrium [20]. Methylamine $(10 \mathrm{mmol} / \mathrm{l})$ did not alter the initial rates of insulin binding (Fig.6a) or internalization (Fig.6b) during the first 15$30 \mathrm{~min}$ at $37^{\circ} \mathrm{C}$. After $30 \mathrm{~min}$, the levels of intracellular ${ }^{125}$ I-insulin increased dramatically (two-three fold) in methylamine-treated cultures from all three gestational ages. Furthermore, methylamine inhibited the degradation of internalized ${ }^{125}$ I-insulin by $200-400 \%$ compared to untreated hepatocytes (Fig. 7). Thus, the marked increase in intracellular radioactivity observed in the presence of methylamine was due to an accumulation of intact hormone.

Lastly, we evaluated the effect of methylamine on insulin-stimulated glycogenesis in dexamethasone pretreated hepatocytes, to determine whether interference with intracellular processing of insulin affects its biological activity. Methylamine caused a dose-dependent inhibition of insulin-stimulated glycogen accumulation in 21day fetal hepatocytes, with no effect on basal glycogen levels (data not shown). At a concentration of $10 \mathrm{mmol} / \mathrm{l}$, methylamine almost completely inhibited the insulinstimulated increase in both total cellular glycogen content (Fig. 8a) and ${ }^{14} \mathrm{C}$-glucose incorporation into glycogen (Fig. 8b) in 19 and 21-day cells without affecting basal glycogen synthesis. No glycogen response to insulin could be induced in 17-day fetal rat hepatocytes in control or methylamine-treated cultures.

\section{Discussion}

We have demonstrated that hepatocytes isolated from fetal rats during late gestation exhibited both degradative and retroendocytotic pathways for processing intracellular insulin, as has been previously reported for adult liver cells [13]. In addition, there were differences in insulin binding and processing with gestational age. Fetal hepatocytes exhibited a dramatic increase in their capacity to bind insulin, particularly between days 17 and 19. Similar developmental changes have been reported for human umbilical cord blood monocytes [21,22] and fetal rat liver plasma membranes [23]. Based upon the results of Scatchard analysis, the developmental increase in insulin binding was due to the appearance of low affinity binding sites 


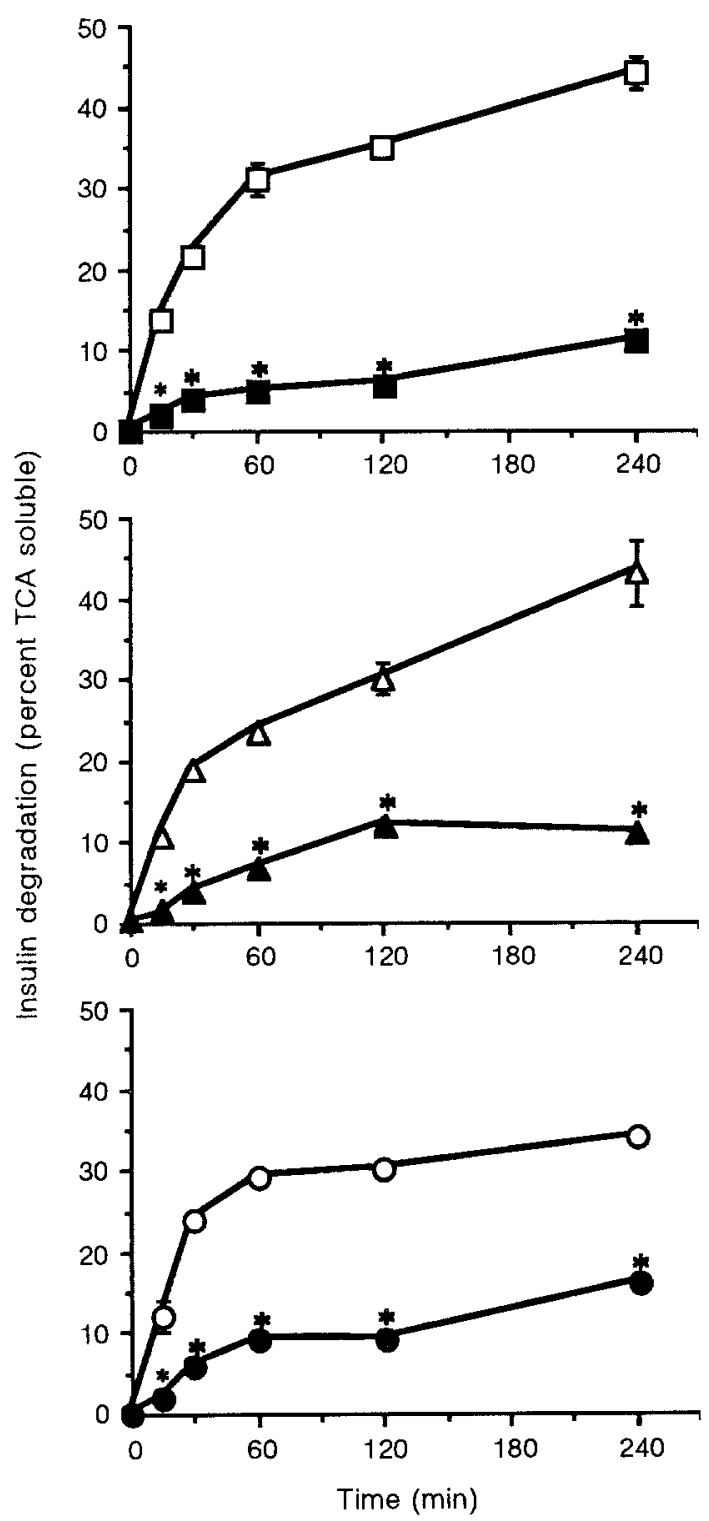

Fig. 7. Inhibition of ${ }^{125}$ I-insulin degradation by methylamine. Hepatocyte cultures $(17(\square), 19(\triangle)$, and $21(O)$ days of gestation) were incubated at $37^{\circ} \mathrm{C}$ with ${ }^{125} \mathrm{I}$-insulin $(0.5 \mathrm{nmol} / \mathrm{l}) \pm$ unlabelled insulin and methylamine $(10 \mathrm{mmol} / \mathrm{l}$; closed symbols). At the indicated times, the monolayers were rapidly rinsed four times with ice-cold PBS and extracted in $1 \mathrm{~mol} / \mathrm{l}$ acetic acid, $4 \mathrm{~mol} / \mathrm{l}$ urea, and $0.1 \%$ Triton X-100. The radioactivity soluble (degraded insulin) in 10\% icecold TCA was determined. The results are expressed as a percentage of the total cell-associated radioactivity which is soluble in TCA and have been corrected for non-specific degradation (degradation in the presence of excess unlabelled insulin) and differences in protein content. The data for control cultures are depicted in open symbols and the methylamine-treated cultures in closed symbols. Means \pm SEM for triplicate cultures (three determinations per culture) are shown. $* p<0.01$ for the differences between control and methylamine-treated cultures of the same age at the indicated times

or negative cooperativity by 19 days of gestation. However, our results are also consistent with the possibility that the increase in binding, observed at high (10$100 \mathrm{nmol} / \mathrm{l}$ ) concentrations of insulin, was due to cross-reactivity with type I IGF receptors. Indeed, other investigators have suggested that the glycogenic actions of insulin may be mediated, in part, through interaction with receptors for IGF-I in 20-day-old fetal rat hepatocytes [24] and HEP-G2 human hepatoma cells [25]. Our data did not permit us to differentiate between these possibilities.

Insulin binding to cultured fetal rat hepatocytes was time and temperature dependent. At $37^{\circ} \mathrm{C}$, total cell-associated ${ }^{125}$ I-labelled material decreased after $30 \mathrm{~min}$ of incubation which did not occur when binding was studied at $4^{\circ} \mathrm{C}$. Such binding kinetics and temperature probably reflect internalization of hormone-receptor complexes, followed by ${ }^{125}$ I-insulin degradation and expulsion of ${ }^{125} \mathrm{I}$-labelled insulin and its degradation products $[12,13]$. The rates of both processes tended to diminish with increasing gestational age.

To study the fate of internalized insulin, we analysed the ${ }^{125}$ I-labelled material associated with cells and the culture medium. However, unlike the previous studies on insulin processing by fetal hepatocytes $[7,8]$, we have included a procedure (acid-saline dissociation) for removing cell surface bound ${ }^{125}$ I-insulin prior to harvesting cell extracts and collecting ${ }^{125}$ I-labelled material released into the medium. Such an approach, previously used to characterize insulin trafficking by adult rat adipocytes [12] and hepatocytes [13], has made it possible to distinguish between intact insulin released from inside the cell and that dissociated from the cell surface. In adult tissues $[12,13]$, intracellular insulin was reported to traverse either a classic degradative pathway or a retroendocytotic pathway in which intact insulin was released from the cells. Similarly, we found that ${ }^{125}$ I-insulin internalized by fetal hepatocytes was either rapidly released $\left(\mathrm{t}_{1 / 2}<6 \mathrm{~min}\right)$ intact, or targeted for degradation. All of the intact insulin destined for retroendocytosis (approximately $50 \%$ of the total cell-associated insulin) was released from the cells during the first $15-20 \mathrm{~min}$, suggesting that the insulin remaining within the cells after 20 min was probably committed to a degradative pathway. This difference in rates of release for intact and degraded insulin is consistent with the processing of insulin through two distinct pathways. The gradual decrease in extracellular intact insulin levels after 60-120 min probably reflected rebinding and endocytosis of the ${ }^{125} \mathrm{I}$-insulin which had been expelled, rather than degradation within the medium.

While the ability of intact fetal rat liver to sequester and degrade ${ }^{125} \mathrm{I}$-insulin was previously reported to increase between days 17 and 21 of gestation in vivo [9], a number of factors complicated interpretation of those results. Both endogenous insulin levels [26] and the specific activity of the ${ }^{125}$ I-insulin, as well as the cellular composition of the liver [9], changed dramatically during this period of fetal development. In contrast, our in vitro system permitted us to examine insulin processing at the cellular level throughout late gestation. At a low hormone concentration $(0.5 \mathrm{nmol} / 1)$, insulin binding did not change during late gestation and the rates of insulin processing did not change significantly with gestational age. But at higher insulin concentrations, the large increases in binding capacity observed between 17 and 19 days of gestation would probably result in a concomitant increase in receptormediated insulin processing, similar to that reported in vivo [9]. 


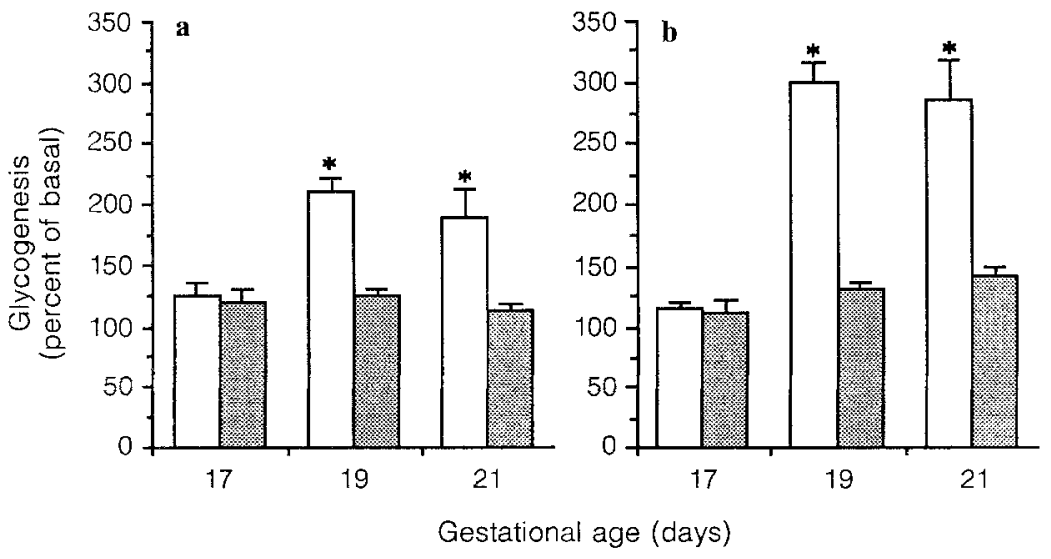

Fig.8 a,b. Inhibition of insulin-stimulated glycogenesis by methylamine. Fetal rat hepatocytes were pre-incubated for $48 \mathrm{~h}$ with dexamethasone $(100 \mathrm{nmol} / \mathrm{l})$. The cultures were then incubated with $1.0 \mu \mathrm{Ci} \mathrm{D}-\mathrm{U}-{ }^{14} \mathrm{C}$-glucose in the presence and absence of insulin (100 nmol/l) with ( $)$ and without ( $\square)$ methylamine $(10 \mathrm{mmol} / \mathrm{l})$. After $4 \mathrm{~h}$ at $37^{\circ} \mathrm{C}$, both total cellular glycogen levels (a) and glucose incorporation into glycogen (b) were determined. The results are

To explore the relationship between insulin processing and its biological activity, we compared the effects of the acidotropic (formerly lysosomotropic; [27]) agent, methylamine, on insulin processing to its influence on insulinstimulated glycogenesis. Methylamine did not change the amount of ${ }^{125} \mathrm{I}$-insulin initially bound to the hepatocytes, nor did it appear to affect the rate of insulin internalization. Methylamine did, however, inhibit the intracellular degradation of ${ }^{125} \mathrm{I}$-insulin, resulting in an increase in total cell-associated radioactivity. These results are consistent with the expected actions of acidotropic amines, which permit internalization of ligands, but prevent their subsequent processing by raising intraendosomal $\mathrm{pH}[11,20$, 28]. Methylamine $(10 \mathrm{mmol} / \mathrm{l})$ also inhibited insulinstimulated glycogen synthesis in hormone-responsive 19and 21-day fetal rat hepatocytes without affecting basal glycogenesis. Likewise, treatment of 18-day fetal rat hepatocytes with chloroquine, another acidotropic agent, also inhibited insulin-stimulated glycogenesis [7, 8]. Thus, our results support previous findings in that some aspect of insulin-receptor processing was required for expression of the glycogenic action of insulin in fetal rat hepatocytes capable of responding to the hormone. However, our finding that 17-day fetal rat hepatocytes, pre-treated for $48 \mathrm{~h}$ with dexamethasone $(100 \mathrm{nmol} / 1)$, did not synthesize glycogen in response to insulin, was rather surprising in view of reports by Plas et al. [29, 30] that insulin-stimulated glycogenesis was induced by glucocorticoids in fetal rat hepatocytes isolated from 15- and 17-day-old rat fetuses, respectively. Subtle differences in our experimental systems, such as culture medium (e.g. presence of serum), treatment conditions (e.g. duration of exposure to insulin), or estimation of gestational age, might result in such a discrepancy.

Since acidotropic compounds, such as methylamine, inhibit receptor processing as well as that of the ligand [11, 14], insulin receptor trafficking may represent another key event in the hormonal regulation of glycogen syn- expressed as a percentage of basal (absence of insulin) glycogen synthesis; means \pm SEM's for triplicate cultures are shown. Basal glycogen levels increased with gestational age from $14 \pm 3$ to $51 \pm 6$ $\mu \mathrm{g} / \mathrm{mg}$ protein in 17 and 21 day fetal hepatocytes, respectively. In the absence of insulin, methylamine did not affect glycogen content or ${ }^{14} \mathrm{C}$-glucose incorporation into glycogen. * $p<0.01$ for the differences between insulin-stimulated and basal at the indicated age

thesis. In this regard, Soubigou et al. [31] have shown that more than one cycle of insulin receptor endocytosis (after which internalized receptors return to the plasma membrane) may be necessary for development of a maximal glycogenic response to insulin. With increased receptor availability, the amount of intact insulin released by fetal hepatocytes via retroendocytosis may be critical for maintaining the local extracellular insulin concentrations required for complete expression of the glycogenic action of insulin. The disappearance after $120 \mathrm{~min}$ of the intact ${ }^{125} \mathrm{I}-$ insulin which had been released by fetal hepatocytes into the medium is consistent with the hypothesis that the hepatocytes were rebinding the insulin which had been expelled. No insulin degrading activity was present in the medium. Thus, we suggest that when the insulin concentrations in the medium are sufficiently high to stimulate a biological response, then internalized insulin is routed through the degradative pathway; however, when extracellular insulin levels are low (as in our experiments; $0.5 \mathrm{nmol} / \mathrm{l}$ ), then the internalized ligand is more likely to be released intact rather than degraded. Indeed, both the endocytotic uptake [32] and the retroendocytotic release [33] of insulin have been shown to be regulated by the extracellular insulin concentration.

We conclude that insulin binding to cultured fetal hepatocytes increased dramatically as a function of donor age, between 17 and 19 days of gestation. In contrast, the rate of insulin processing tended to decrease during late gestation. Both degradative and retroendocytotic pathways for processing insulin were functional in fetal rat hepatocytes by 17 days of gestation. Further, some aspect of insulin-receptor processing was functionally related to expression of the glycogenic action of insulin in responsive hepatocytes isolated from rat fetuses after 17 days of gestation.

Acknowledgements. The authors gratefully acknowledge the technical assistance of Ms. B. A. Toly. This work was supported in part by USPHS Grant \# HD-14021. 


\section{References}

1. Pederson J (1975) Fetal macrosomia. In: Sutherland HW, Stowers $M$ (eds) Carbohydrate metabolism in pregnancy and the newborn. Churchill Livingston, London, pp 247-273

2. Susa JB, McCormick KL, Widness JA, Singer DB, Adamsons K, Schwartz R (1979) Chronic hyperinsulinemia in the fetal rhesus monkey: effects on fetal growth and composition. Diabetes 28 : 1058-1063

3. Hill DJ, Milner RDG (1985) Insulin as a growth factor. Pediatr Res 19: 879-886

4. King GL, Kahn CR, Rechler MM, Nissley SP (1980) Direct demonstration of separate receptors for growth and metabolic activities of insulin and multiplication-stimulating activity using antibodies to the insulin receptor. J Clin Invest 66: 130-140

5. Banskota NK, Taub R, Zellner K, Olsen P, King GL (1989) Characterization of induction of protooncogene c-myc and cellular growth in human vascular smooth muscle cells by insulin and IGF-I. Diabetes 38: 123-129

6. Menuelle P, Plas C (1981) Relationship between insulin binding and glycogenesis in cultured fetal hepatocytes. Diabetologia 20: 647-653

7. Plas C, Desbuquois B (1982) Receptor-mediated insulin degradation and insulin-stimulated glycogenesis in cultured foetal hepatocytes. Biochem J 202: 333-341

8. Pringault EE, Plas C, Desbuquois B (1985) Reutilization of insulin receptor and hormonal response in cultured foetal hepatocytes: the effect of chloroquine and vinblastine. Biol Cell 52:1322

9. Sodoyez-Goffaux F, Sodoyez JC, Vos CJ de (1982) Maturation of liver handling of insulin in the rat fetus. Diabetes 31:60-69

10. Duckworth WC (1988) Insulin degradation: mechanisms, products, and significance. Endocrine Rev 9: 319-345

11. Bergeron JJM, Cruz J, Khan MN, Posner BI (1985) Uptake of insulin and other ligands into receptor-rich endocytotic components of target cells: the endosomal apparatus. Ann Rev Physiol 47:383-403

12. Marshall S (1985) Degradative processing of internalized insulin in isolated adipocytes. J Biol Chem 260: 13517-13523

13. Levy JR, Olefsky JM (1987) The trafficking and processing of insulin and insulin receptors in cultured rat hepatocytes. Endocrinol 121: 2075-2086

14. Marshall S (1985) Kinetics of insulin receptor internalization and recycling in adipocytes. J Biol Chem 260: 4136-4144

15. Richman RA, Benedict MR, Florini JR, Toly BA (1985) Hormonal regulation of somatomedin secretion by fetal rat hepatocytes in primary culture. Endocrinol 116:180-188

16. Lowry OH, Rosenbrough NJ, Farr AL, Randall RJ (1951) Protein measurement with the Folin-phenol reagent. J Biol Chem 193: 265-275

17. Haigler HT, Willingham MC, Pastan I (1980) Inhibitors of ${ }^{125} \mathrm{I}-$ epidermal growth factor internalization. Biochem Biophys Res Comm 94: 630-637

18. Hammons GT, Jarett L (1980) Lysosomal degradation of receptor-bound ${ }^{125}$ I-labelled insulin by rat adipocytes: its characterization and dissociation from the short-term biological effects of insulin. Diabetes 29: 475-486
19. Handel E van (1965) Estimation of glycogen in small amounts of tissue. Anal Biochem 11:256-265

20. Krogstad DJ, Schlesinger PH (1987) Acid-vesicle function, intracellular pathogens, and the action of chloroquine against Plasmodium falceparum. N Engl J Med 317: 542-549

21. Thorssen AV, Hintz RL (1977) Insulin receptors in the newborn: increase in receptor affinity and number. N Engl J Med 297: 908912

22. Neufeld ND, Kaplan SA, Lippe BM (1981) Monocyte insulin receptors in infants of strictly controlled diabetic mothers. J Clin Endocrinol Metab 52: 473-476

23. Neufeld ND, Scott M, Kaplan SA (1980) Ontogeny of the mammalian insulin receptor: studies of human and rat fetal liver plasma membranes. Dev Biol 78: 151-160

24. Freemark M, D'Ercole AJ, Handwerger S (1985) Somatomedin$\mathrm{C}$ stimulates glycogen synthesis in fetal rat hepatocytes. Endocrinol 116: 2578-2582

25. Verspohl EJ, Roth RA, Vigneri R, Goldfine ID (1984) Dual regulation of glycogen metabolism by insulin and insulin-like growth factors in human hepatoma cells (HEP-G2). J Clin Invest 74: $1436-1443$

26. Watts C, Gain K, Sandin PL (1976) Glucose homeostasis in the developing rat. I. Blood glucose and immunoreactive insulin in the later stages of gestation of the fetal rat. Biol Neonate 30: 88 94

27. Duve C de (1983) Lysosomes revisited. Eur J Biochem 137: 391397

28. Galloway CJ, Dean GE, Marsh M, Rudnick G, Mellman I (1983) Acidification of macrophage and fibroblast endocytotic vesicles in vitro. Proc Natl Acad Sci USA 80: 3334-3338

29. Plas C, Nunez J (1976) Role of cortisol on the glycogenolytic effect of glucagon and on the glycogenic response to insulin in fetal hepatocyte culture. J Biol Chem 251: 1431-1437

30. Plas C, Forest N, Pringault E, Menuelle P (1982) Contribution of glucose and gluconeogenic substrates to insulin-stimulated glycogen synthesis in cultured fetal hepatocytes. J Cell Physiol 113: $475-480$

31. Soubigou P, Pringault E, Plas C (1986) Cell-surface insulin receptor cycling and its implication in the glycogenic response in cultured foetal hepatocytes. Biochem J 239:609-61.5

32. Capentier JL, Robert A, Grunberger G, Obberghen E van, Freychet P, Orci L, Gorden P (1986) Receptor-mediated endocytosis of polypeptide hormones is a regulated process: inhibition of $\left[{ }^{125} \mathrm{I}\right]$ iodoinsulin internalization in hypoinsulinemic diabetes of rat and man. J Clin Endocrinol Metab 63: 151-155

33. Levy JR, Olefsky JM (1987) The effect of insulin concentration on retroendocytosis in isolated rat adipocytes. Endocrinology $120: 450-456$

Received: 4 June 1991

and in revised form: 2 September 1991

Dr. M.R. Benedict

Department of Pediatrics

SUNY Health Science Center at Syracuse

Syracuse, NY 13210

USA 